\title{
Three Factor 11 Mutations Associated with Factor XI Deficiency in a Turkish Family
}

\author{
Türk Bir Ailede Faktör XI Yetersizliği ile Ilişkili Üç Faktör 11 Mutasyonu
}

\author{
(D) Veysel Sabri Hançer ${ }^{1}$, (D) Zafer Gökgöz ${ }^{2}$, (D) Murat Büyükdoğan ${ }^{1}$ \\ 1 Istinye University Faculty of Medicine, Department of Medical Genetics, Istanbul, Turkey \\ 2 Medicana International Ankara Hospital, Clinic of Hematology, Ankara, Turkey
}

To the Editor,

Factor $\mathrm{XI}$ (FXI) is a homodimeric serine protease, which is produced in the liver and circulates in the plasma complexed with high-molecular-weight kininogen. FXI plays an important role in the amplification of the initial coagulation response via a positive feedback mechanism for the generation of additional thrombin $[1,2,3,4]$. Congenital FXI deficiency is characterized by decreased levels or activity of FXI in the plasma and may cause an inherited bleeding disorder. The FXI gene is located on 4q3435 and consists of 15 exons.

The index case was a 10 year-old-boy with bleeding diathesis (excessive bleeding after tooth extraction). His activated partial thromboplastin time (aPT) was $84.3 \mathrm{~s}$ (normal range: 32-39 s), $\mathrm{FXI}$ activity was $0 \%$, and he was diagnosed with FXI deficiency. His parents were related. The father had a mild bleeding tendency with prolonged aPT (48.2 s). FXI activity was found to be $4 \%$. The mother and the second child had no bleeding history with mildly decreased FXI activities ( $40 \%$ and $60 \%$, respectively). We performed a mutational analysis for the whole family, including the patient's grandparents. Genomic DNA was extracted from whole blood. All exons and approximately 25-bp exon-intron boundaries of the factor 11 (F11) gene were amplified using sets of designed primers. After polymerase chain reaction, the amplified fragments were sequenced.

The patient and his father had a p.Ala109Thr (ENST00000492972.6, p.A109T, c.325 G>A, rs768474112) homozygous mutation for F11; the patient also had novel heterozygous p.1454T and p.Y472* mutations (Figure 1). The presence of a homozygous p.A109T mutation in the father and the index patient caused severe FXI deficiency. The mother and the second child had heterozygous p.I454T and p.Y472* mutations. As shown in Figure 2, p.1454T and p.Y $472^{*}$ heterozygosity moderately decreases the activity of FXI. In this family, we found two novel mutations, p.I454T and p.Y472*, associated with a homozygous p.A109T mutation. p.I454T is probably damaging with a PolyPhen score of 0.9. This is the first case reported in the literature with homozygous p.A109T. Previously, Guella et al. [5] reported a heterozygous p.A109T mutation in an Italian family with FXI deficiency. They showed that exon-skipping had occurred due to a heterozygous p.A109T mutation and they explained that the unchanged enzyme activity was due to a non-sense mediated RNA decay mechanism. With this mechanism, due to p.A109T mutation, incorrectly spliced transcripts are not allowed to exit the nucleus to the cytoplasm. Our cases confirmed their results, such that a heterozygous p.A109T mutation did not affect enzyme activity; the enzyme activity of a person who has two heterozygous mutations (p.Y472* and p.I454T) is the same as that of someone

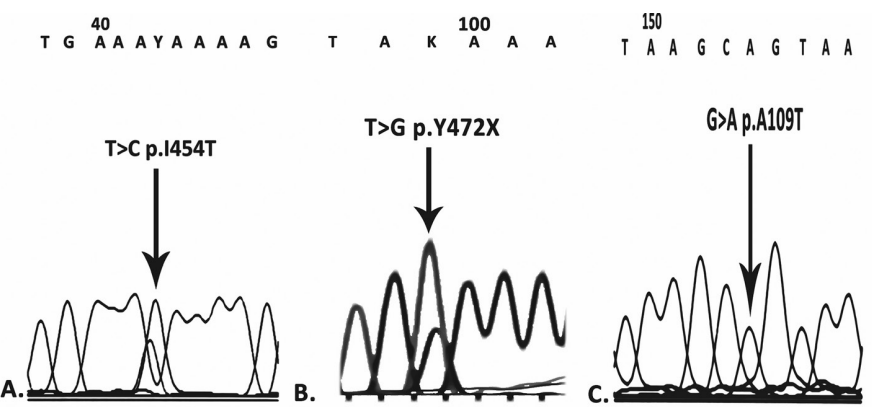

Figure 1. Electropherogram results.
I

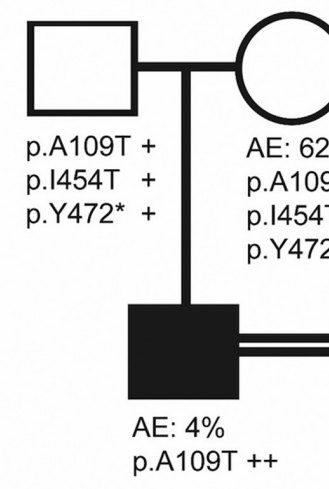

III

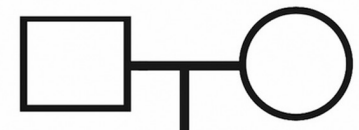

AE: $126 \%$ Wild Type

AE: $61 \%$

p.1454T +

p. $Y 472^{*}+$
II

$1454 T+$
$Y 472^{*}+$

P. 
who has three heterozygous mutations (p.A109T, p.Y472*, and p.I454T). However, when p.A109T was homozygous, like in our index patient and his father, the enzyme activity decreased by approximately $96 \%$ as shown in the pedigree. Another interesting point was the presence of a homozygous p.A109T mutation in the patient while his mother had no p.A109T mutation. This may be explained by a second-hit de novo mutation in the index case. Further expression studies evaluating the effects of these mutations will improve our understanding of the functional and structural features of the FXI enzyme.

Keywords: Factor XI, Mutation, Family

Anahtar Sözcükler: Faktör XI, Mutasyon, Aile

Conflict of Interest: The authors of this paper have no conflicts of interest, including specific financial interests, relationships, and/or affiliations relevant to the subject matter or materials included.

\section{References}

1. Thompson RE, Mandle R Jr, Kaplan AP. Studies of binding of prekallikrein and factor XI to high molecular weight kininogen and its light chain. Proc Natl Acad Sci USA 1979;76:4862-4866.

2. Geng Y, Verhamme IM, Smith SM, Sun MF, Matafonov A, Cheng Q, Smith $\mathrm{SA}$, Morrisey JH, Gailani D. The dimeric structure of factor $\mathrm{XI}$ and zymogen activation. Blood 2013;121:3962-3969.

3. Kravtsov DV, Wu W, Meijers JC, Sun MF, Blinder MA, Dang TP, Wang $H_{\text {, }}$ Gailani D. Dominant factor XI deficiency caused by mutations in the factor XI catalytic domain. Blood 2004;104:128-134.

4. Whelihan MF, Orfeo T, Gissel MT, Mann KG. Coagulation procofactor activation by factor Xla. J Thromb Haemost 2010;8:1532-1539.

5. Guella I, Solda G, Spena S, Asselta R, Ghiotto R, Tenchini ML, Castaman G, Duga $S$. Molecular characterization of two novel mutations causing factor $\mathrm{XI}$ deficiency: a splicing defect and a missense mutation responsible for a CRM+ defect. Thromb Haemost 2008;99:523-530.
Address for Correspondence/Yazışma Adresi: Veysel Sabri HANÇER, M.D. İstinye University Faculty of Medicine, Department of Medical Genetics, İstanbul, Turkey

-mail : vshancer@yahoo.com ORCID-ID: orcid.org/0000-0003-2994-1077
Received/Geliş tarihi: April 01, 2017 Accepted/Kabul tarihi: September 25, 2017

DOI: 10.4274/tjh.2017.0140 